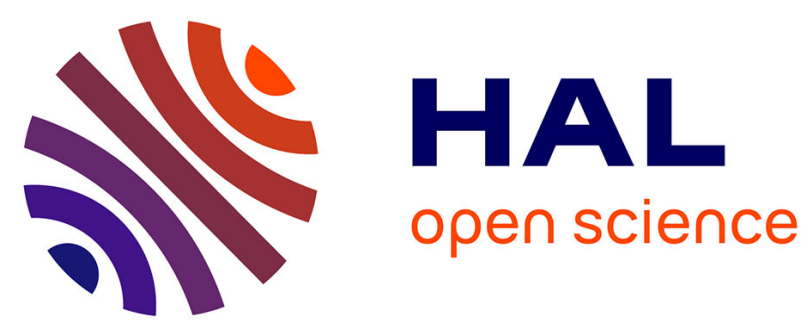

\title{
Synthesis of a Hexavalent Betulinic Acid Derivative as a Hemagglutinin- Targeted Influenza Virus Entry Inhibitor
}

\author{
Yingying Chen, Xinchen Wang, Yinbiao Zhu, Longlong Si, Bo Zhang, \\ Yongmin Zhang, Lihe Zhang, Demin Zhou, Sulong Xiao
}

\section{To cite this version:}

Yingying Chen, Xinchen Wang, Yinbiao Zhu, Longlong Si, Bo Zhang, et al.. Synthesis of a Hexavalent Betulinic Acid Derivative as a Hemagglutinin- Targeted Influenza Virus Entry Inhibitor. Molecular Pharmaceutics, 2020, 17 (7), pp.2546-2554. 10.1021/acs.molpharmaceut.0c00244 • hal-02924754

\section{HAL Id: hal-02924754 \\ https://hal.sorbonne-universite.fr/hal-02924754}

Submitted on 28 Aug 2020

HAL is a multi-disciplinary open access archive for the deposit and dissemination of scientific research documents, whether they are published or not. The documents may come from teaching and research institutions in France or abroad, or from public or private research centers.
L'archive ouverte pluridisciplinaire HAL, est destinée au dépôt et à la diffusion de documents scientifiques de niveau recherche, publiés ou non, émanant des établissements d'enseignement et de recherche français ou étrangers, des laboratoires publics ou privés. 


\section{Synthesis of a Hexavalent Betulinic Acid Derivative as a Hemagglutinin- Targeted Influenza Virus Entry Inhibitor}

Yingying Chen ${ }^{\mathrm{a}, \dagger}$, Xinchen Wang ${ }^{\mathrm{a}, \dagger}$, Yinbiao $\mathrm{Zhu}^{\mathrm{a}, \uparrow}$, Longlong $\mathrm{Si}^{\mathrm{a}, \mathrm{c}}$, Bo Zhang ${ }^{\mathrm{d}}$, Yongmin Zhang ${ }^{\mathrm{b}}$, Lihe Zhang ${ }^{\mathrm{a}}$, Demin Zhou ${ }^{\mathrm{a}}$, and Sulong Xiao ${ }^{\mathrm{a}, \mathrm{e}^{*}}$

${ }^{a}$ State Key Laboratory of Natural and Biomimetic Drugs, School of Pharmaceutical Sciences, Peking University, Beijing 100191, China

${ }^{b}$ Sorbonne Université, Institut Parisien de Chimie Moléculaire, CNRS UMR 8232, 4 place Jussieu, 75005 Paris, France

${ }^{c}$ Wyss Institute for Biologically Inspired Engineering, Harvard University, Boston, MA 02115, USA.

${ }^{d}$ Center for Translational Medicine, Chinese Academy of Medical Sciences and Peking Union Medical College, Beijing 100730, China

e State Key Laboratory of Phytochemistry and Plant Resources in West China, Kunming Institute of Botany, Chinese Academy of Sciences, Kunming 650201, China

Address correspondence to Associate Professor Sulong Xiao State Key Laboratory of Natural and Biomimetic Drugs, School of Pharmaceutical Sciences Peking University 38 Xueyuan Road, Beijing, China 100191 
Tel: 86-10-8280-5063

Fax: 86-10-8280-5063

Email: slxiao@bjmu.edu.cn

$\dagger$ These authors contributed equally to this work. 
For Table of Contents Use Only

Synthesis of a Hexavalent Betulinic Acid Derivative as a Hemagglutinin-Targeted

\section{Influenza Virus Entry Inhibitor}

Yingying Chen ${ }^{\mathrm{a}, \uparrow}$, Xinchen Wang ${ }^{\mathrm{a}, \uparrow}$, Yinbiao Zhu ${ }^{\mathrm{a}, \dagger}$, Longlong $\mathrm{Si}^{\mathrm{a}, \mathrm{c}}$, Bo Zhang ${ }^{\mathrm{d}}$, Yongmin Zhang ${ }^{\mathrm{b}}$, Lihe Zhang ${ }^{\mathrm{a}}$, Demin Zhou ${ }^{\mathrm{a}}$, and Sulong Xiao ${ }^{\mathrm{a}, \mathrm{e}^{*}}$

Table of Contents Graphic

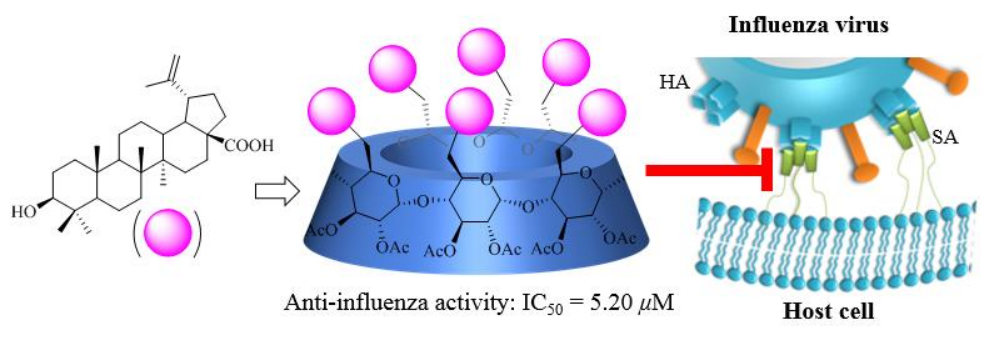




\section{- ABSTRACT}

Naturally occurring pentacyclic triterpenes, such as betulinic acid and its derivatives, exhibit various pharmaceutical activities and have been the subject of great interest, in particular for their antiviral properties. Here, we found a new anti-influenza virus conjugate, hexakis 6-deoxy-6-[4- $N$-(3 $\beta$-hydroxy-lup-20(29)-en-28oate)aminomethyl-1H-1,2,3-triazol-1-yl]-2,3-di-O-acetyl- $\alpha$-cyclodextrin $\quad(C Y Y 1-11$, 1), in a minilibrary of pentacyclic triterpene-cyclodextrin conjugates by performing a cell-based screening assay and then exploring the underlying mechanisms. Our results showed that conjugate $\mathbf{1}$ possessed a high level activity against influenza virus A/WSN/33, with an $\mathrm{IC}_{50}$ value of $5.20 \mu \mathrm{M}$ (SI > 38.4). Study of the mechanism of action indicated that conjugate $\mathbf{1}$ inhibited viral replication by directly targeting the influenza hemagglutinin protein $\left(K_{\mathrm{D}}=1.50 \mu \mathrm{M}\right)$, thus efficiently preventing the attachment of the virion to its receptors on host cells and subsequent infection. This study suggests that multivalent betulinic acid derivatives have possible use as a new class of influenza virus entry inhibitors.

\section{- KEYWORDS:}

betulinic acid; $\alpha$-cyclodextrin; influenza virus; entry inhibitor 


\section{- INTRODUCTION}

Influenza viruses are negative-sense, single-stranded, segmented RNA viruses that belong to the Orthomyxoviridae family. These viruses have an envelope containing a lipid bilayer, with a layer of matrix protein on the inside and spike-like surface projections of glycoproteins on the outerside, wrapped around a central core and form rough spherical particles of 80 to $120 \mathrm{~nm}$ in diameter. ${ }^{1} \mathrm{Up}$ till now, four antigenic types of influenza virus (i.e., A, B, C, and D) have been recognized. Among these, type A has caused a high rate of morbidity and mortality in humans throughout history. Since 1900, four notorious influenza pandemics have occurred with the emergence of novel influenza A viruses, including the Spanish Flu in1918, the Asian Flu in 1957, the Hong Kong Flu in 1968 and the Mexican Flu in 2009, which not only caused over 45 million deaths but also led to great economic losses worldwide. ${ }^{2}$ The WHO estimates that influenza leads to approximately 290,000 to 650,000 deaths every year. ${ }^{3}$ Influenza vaccines and antiviral drugs are the main strategies for preventing and treating emerging influenza infections. However, vaccination is not a realistic option for a rapidly spreading influenza pandemic, as it takes substantial time to identify the virus and generate antibodies against it. ${ }^{4}$ The use of antiviral drugs is preferred in pandemic situations until an effective vaccine is available. To date, three classes of anti-influenza drugs have been approved by the FDA for clinical use, including M2 ion channel blockers (amantadine and rimantadine), neuraminidase (NA) inhibitors (oseltamivir, zanamivir, and peramivir), and polymerase acidic protein (PA) inhibitor (baloxavir marboxil). However, the rapid development of resistant influenza variants after drugs 
treatment and associated side effects have reduced the effectiveness of M2 blockers ${ }^{5,6}$ and limited the use of NA and PA inhibitors. ${ }^{7,8}$ Therefore, it is urgently necessary to develop new antiviral drugs and combination therapies targeting different steps in the virus lifecycle to suppress seasonal and pandemic influenza.

The specific recognition and binding of the viral surface glycoprotein hemagglutinin (HA) to the host cell receptor $\alpha$-sialic acid is the critical step in the entry of influenza virus. HA is a homotrimeric molecule that is shaped like a cylinder and is approximately $135 \AA$ in length. ${ }^{9}$ According to a small-angle neutron scattering study, the HA trimers are 105 to $109 \AA$ apart from each other, and there are $300-400$ copies of HA on the surface of influenza virus. ${ }^{9}, 10$ Therefore, the entry of influenza virus into host cells typically involves the simultaneous binding of multiple copies of HA trimers to multiple copies of sialic acids, which provides an appealing strategy for medicinal chemists to design multivalent molecules to block viral protein-host receptor interactions. $^{9}$ Such multivalent molecules, i.e., linear polymers, ${ }^{11-13}$ dendritic polymers, ${ }^{14}$ nanoparticles, ${ }^{15-17}$ polyazido-calix [4] arenes, ${ }^{18}$ have recently been prepared and shown to be extremely potent antiviral inhibitors of influenza A virus.

Previously, we have designed and synthesized a series of multivalent pentacyclic triterpene derivatives based on $\beta$-cyclodextrin $(\beta$-CD) scaffold as influenza entry inhbitors. ${ }^{19}$ Three heptavalent pentacyclic triterpene- $\beta$-CD conjugates exhibited a broad spectrum of inhibitory effects on multiple influenza strains with $\mathrm{IC}_{50}$ values at 2.47$14.90 \mu \mathrm{M}$. Li et al. have also reported that natural pentacylic triterpene-pendant copolymers, such as PNOEG-block and ran-PNGA, have low cytotoxicity toward L929 
cells. ${ }^{20}$ Recently, multivalent oleanolic acid derivatives based on human serum albumin (HSA) scaffold have been designed as nonglycosylated neomucin mimics for the specific capture of influenza viruses. ${ }^{21}$ Those studies rationalize the feasibility of developing anti-influenza virus drug based on multivalent natural pentacyclic triterpenes.

As a step towards the structural modification of pentacyclic triterpenes as antiviral inhibitors, ${ }^{19,}{ }^{22-24}$ we believed it would be valuable to prepare a range of diverse pentacyclic triterpene derivatives to better explore the structure-activity relationship and molecular mechanism. Betulinic acid (BA, 3 $\beta$-hydroxy-lup-20(29)-en-28-oic acid), a naturally occurring lupane-type pentacyclic triterpene, is widely distributed throughout the plant kingdom, notably in the bark of white birch trees. ${ }^{25} \mathrm{BA}$ and its semisynthetic derivatives possess good anti-HIV activity. ${ }^{26-31}$, and two of these derivatives have entered clinical trials. ${ }^{32-35}$ The 3-O-(3',3'-dimethylsuccinyl) betulinic acid (bevirimat), also known as PA-457, DSB or YK-FH312, has completed phase III clinical trials as a first-generation maturation inhibitor drug for HIV. ${ }^{36,37}$ Recently, an orally active, second-generation HIV-1 maturation inhibitor, BMS-955176, has been reported with an improved antiviral spectrum and Gag polymorphic coverage. ${ }^{38,} 39$ However, the anti-influenza activity reported for BA are rare due to its weak activity. ${ }^{40,}$ ${ }^{41}$ For example, a report by Baltina illustrates that BA only showed weak anti-influenza activity with $\mathrm{IC}_{50}$ over $200 \mu \mathrm{M} .{ }^{40}$ However, several derivatives of $\mathrm{BA}$, such as betulinic aldehyde and 28-ortho-methoxycynnamoyl betulin, have shown potent anti-influenza activity. ${ }^{40,42}$ Given the advantage of conjugation of $\mathrm{CD}$ with multiple copies of BA, we 
were wondering whether the anti-influenza activity of BA might be improved synergistically. Evaluation of hexa-, hepta- and octavalent BA-CD conjugates, via a flexible oligo (ethylene glycol) (OEG) linker varying in lengths on the primary face might provide systematic information for further optimization. We report here a hexavalent BA- $\alpha-\mathrm{CD}(\mathrm{CYY} 1-11, \mathbf{1})$, one of such conjugates, that exerted high antiinfluenza $\mathrm{A} / \mathrm{WSN} / 33(\mathrm{H} 1 \mathrm{~N} 1)$ virus activity $\left(\mathrm{IC}_{50}=5.20 \mu \mathrm{M}\right)$ with no significant cytotoxicity (SI > 38.4). The mechanism of action of conjugate 1 against influenza A virus entry activity was further explored.

\section{- MATERIALS AND METHODS}

Materials. The influenza A NP antibody (Cat No. sc-101352, $0.1 \mathrm{mg} / \mathrm{mL}$ ) was obtained from Santa Cruz Biotechnology, Inc. (Santa Cruz, USA), and the GAPDH antibody (Cat No. 60004-1-Ig) was purchased from Proteintech Group, Inc. (Chicago, USA). The influenza A virus H1N1 HA antibody (Cat No. GTX629746) was purchased from GeneTex, Inc. (Santonio, USA). The goat anti-mouse IgG FITC-conjugated secondary antibody (Cat No. GR3217094-2, $2 \mathrm{mg} / \mathrm{mL}$ ) was purchased from Abcam (Cambridge, USA). The anti-rabbit IgG (Cat No. ZB-2301, $1 \mathrm{mg} / \mathrm{mL}$ ) and anti-mouse IgG (Cat No. ZB-2305, $1 \mathrm{mg} / \mathrm{mL}$ ) antibodies coupled to horseradish peroxidase (HRP) were purchased from Sigma-Aldrich (St. Louis, USA). CellTiter-Glo reagent (Cat No. G7572) was purchased from Promega Corp. (Madison, USA). All the other reagents and solvents were purchased commercially and used as received. The results of the CPE assay were measured on an Infinite M2000 PRO $^{\text {TM }}$ plate reader (TECAN Instruments, Switzerland). The SPR experiments were carried outon a Biacore $8 \mathrm{k}$ biosensor system 
and analyzed with Biacore evaluation software (BIA evaluation 1.0.5.) (GE Healthcare Life Sciences, Sweden).

The microwave reactions were carried out on a CEM Discover SP microwave reactor (CEM, North Carolina, USA). ${ }^{1} \mathrm{H}$ NMR and ${ }^{13} \mathrm{C}$ NMR spectra were recorded at room temperature on a Bruker Avance spectrometer operating at $400 \mathrm{MHz}$ or 600 $\mathrm{MHz}$; the chemical shift were expressed in ppm using residual solvent protons as internal standards. ESI-HRMS and MALDI-TOF MS were recorded on an APEX IV FT_MS (7.0 T) spectrometer (Bruker Co., Bremen, Germany) or an AB Sciex TOF/TOFTM 72115 spectrometer (AB SCIEX, Massachusetts, USA). The reactions were monitored by thin-layer chromatography (TLC) on a precoated silica gel $60 \mathrm{~F}_{254}$ plate (layer thickness $0.2 \mathrm{~mm}$; E. Merck, Darmstadt, Germany) and were detected by staining with a yellow solution containing $\mathrm{Ce}\left(\mathrm{NH}_{4}\right)_{2}\left(\mathrm{NO}_{3}\right)_{6} \quad\left(\begin{array}{lll}0.5 & \mathrm{~g}\end{array}\right)$ and $\left(\mathrm{NH}_{4}\right)_{6} \mathrm{Mo}_{7} \mathrm{O}_{24} \cdot 4 \mathrm{H}_{2} \mathrm{O}(24.0 \mathrm{~g})$ in $6 \% \mathrm{H}_{2} \mathrm{SO}_{4}(500 \mathrm{~mL})$, followed by heating. Flash column chromatography was performed on silica gel 60 (200 - 300 $\mu \mathrm{M}$ mesh, Qingdao Haiyang Chemical Co., Ltd., Qingdao, China). All of the other chemical materials were of analytical grade, obtained from commercial sources and used as indicated without further purification unless noted otherwise.

Chemical Synthesis of Hexakis 6-Deoxy-6-[4- $N$-(3/-Hydroxy-lup-20(29)-en28-oate)aminomethyl-1H-1,2,3-Triazol-1-yl]-2,3-Di-O-Acetyl- $\alpha$-CD (CYY1-11, 1$)$. In brief, $\alpha$-CD was converted into hexakis (6-deoxy-6-azide-2,3-di- $O$-acetyl)- $\alpha$-CD 4 with a $71 \%$ yield through a three-step procedure described by Baer et al. ${ }^{43}$ with little modification. $N$-propargyl-3 $\beta$-hydroxy-lup-20(29)-en-28-amide 7 was prepared from 
betulin with a $34 \%$ yield through a four-step procedure according to our previous reported method. ${ }^{44}$ Then, $\mathrm{CuSO}_{4}(16.0 \mathrm{mg}, 0.10 \mathrm{mmol})$ and sodium $L$-ascorbate $(30.0$ $\mathrm{mg}, 0.15 \mathrm{mmol})$ were added to a solution of $4(162.6 \mathrm{mg}, 0.10 \mathrm{mmol})$ and $7(325.3 \mathrm{mg}$, $0.66 \mathrm{mmol})$ in $1: 1 \mathrm{THF}-\mathrm{H}_{2} \mathrm{O}(30 \mathrm{~mL})$. The resulting solution was vigorously heated in a microwave oven at a power of $50 \mathrm{~W}$ at $100{ }^{\circ} \mathrm{C}$ for $1 \mathrm{~h}$. The resultant mixture was then extracted with $\mathrm{CH}_{2} \mathrm{Cl}_{2}(30 \mathrm{~mL} \times 3)$. The combined organics were washed with water, dried over $\mathrm{Na}_{2} \mathrm{SO}_{4}$, filtered and concentrated in vacuo. The crude product was purified by flash column chromatography (eluent: $\mathrm{CH}_{2} \mathrm{Cl}_{2}: \mathrm{CH}_{3} \mathrm{OH}=12: 1$ ) to produce CYY111 (1) as a white foam with a yield of 55\%. ${ }^{1} \mathrm{H} \mathrm{NMR}\left(600 \mathrm{MHz}, \mathrm{CDCl}_{3}\right): \delta 7.58(\mathrm{~s}, 6 \mathrm{H})$, $6.72(\mathrm{~s}, 6 \mathrm{H}), 5.48(\mathrm{t}, 6 \mathrm{H}, J=8.8 \mathrm{~Hz}), 5.37(\mathrm{br} \mathrm{s}, 6 \mathrm{H}), 4.70(\mathrm{~m}, 6 \mathrm{H}), 4.69(\mathrm{~s}, 6 \mathrm{H}), 4.61-$ $4.57(\mathrm{~m}, 18 \mathrm{H}), 4.44(\mathrm{~s}, 6 \mathrm{H}), 4.16(\mathrm{~d}, 6 \mathrm{H}, J=11.9 \mathrm{~Hz}), 3.61(\mathrm{br} \mathrm{t}, 6 \mathrm{H}), 3.18(\mathrm{dd}, 6 \mathrm{H}, J$ $=11.4,4.5 \mathrm{~Hz}), 3.06(\mathrm{dt}, 6 \mathrm{H}, J=10.7,3.9 \mathrm{~Hz}), 2.44(\mathrm{t}, 6 \mathrm{H}, J=10.5 \mathrm{~Hz}), 2.06(\mathrm{~s}, 18 \mathrm{H})$, $2.05(\mathrm{~m}, 6 \mathrm{H}), 2.01(\mathrm{~s}, 18 \mathrm{H}), 1.81-1.78(\mathrm{~m}, 6 \mathrm{H}), 1.67-1.59(\mathrm{~m}, 30 \mathrm{H}), 1.62-1.59(\mathrm{~m}, 12 \mathrm{H})$, 1.55-1.45 (m, 24H), 1.41-1.33 (m, 24H), 1.26-1.17 (m, 24H), 0.96-0.95 (m, 42H), 0.92 (s, 18H), 0.89-0.86 (m, 18H), 0.82, $0.76(\mathrm{~s}$, each $18 \mathrm{H}), 0.67(\mathrm{~d}, 6 \mathrm{H}, J=9.4 \mathrm{~Hz}) ;{ }^{13} \mathrm{C}$ NMR (150 MHz, $\left.\mathrm{CDCl}_{3}\right): \delta 176.6,170.3,169.1,150.7,145.3,124.5,109.5,96.6,79.0$, $76.9,70.6,69.9,55.7,55.4,50.6,50.1,46.6,42.5,40.8,38.9,38.7,38.2,37.7,37.2$, $35.0,34.5,33.6,30.9,29.5,28.0,27.4,25.6,20.9,20.7,19.5,18.3,16.2,16.2,15.4$, 14.6; MALDI-TOF MS (m/z): 4609.82 (calculated for $\mathrm{C}_{258} \mathrm{H}_{384} \mathrm{~N}_{24} \mathrm{NaO}_{48}[\mathrm{M}+\mathrm{Na}]^{+}$); 4609.46 (found experimentally); 4625.80 (calculated for $\mathrm{C}_{258} \mathrm{H}_{384} \mathrm{KN}_{24} \mathrm{O}_{48}[\mathrm{M}+\mathrm{K}]^{+}$); 4625.44 (found experimentally).

Cell Culture. Madin-Darby canine kidney (MDCK) cells and human lung 
adenocarcinoma (A549) cells were donated by Crown Bioscience, Inc. (Santa Clara, USA). The cells were grown in Dulbecco's Modified Eagle Medium (DMEM) (Gibco BRL, Inc., Gaithersburg, USA) supplemented with 10\% fetal bovine serum (FBS) (PAA Laboratories, Linz, Austria) in a humidified incubator supplied with $5 \% \mathrm{CO}_{2}$ and maintained at $37^{\circ} \mathrm{C}$.

Cytotoxicity Assay. The cytotoxicity of conjugate 1 was assessed by the CellTiterGlo assay, a method for monitoring cell proliferation. MDCK cells were seeded at a density of $1 \times 10^{4}$ cells $/ \mathrm{cm}^{2}$ in 96 -well plates containing $1 \%$ FBS overnight and then cultured with increasing concentrations of conjugate $\mathbf{1}$. After $36 \mathrm{~h}$, cytotoxicity was assessed using the CellTiter-Glo luminescent cell viability assay according to the manufacturer's protocol.

Cytopathic Effect (CPE) Reduction Assay. MDCK cells were seeded into 96well plates, cultured overnight and infected with influenza A/WSN/33 virus at a multiplicity of infection (MOI) of 0.2 in DMEM containing 1\% FBS, $20 \mu \mathrm{M}$ test conjugate 1 and $2 \mathrm{mg} / \mathrm{mL}$ TPCK-treated trypsin, with a final concentration of $1 \%$ DMSO in each well. After 36 h, cell viability was measured using CellTiter-Glo assay kit (Promega, Wisconsin, USA) according to the manufacturer's instructions.

Time-of-Addition Experiment. MDCK cells were seeded into 6-well plates at 2 $\times 10^{5}$ cells per well and incubated overnight at $37^{\circ} \mathrm{C}$ under $5 \% \mathrm{CO}_{2}$. The MDCK cells were then infected with the WSN virus at an MOI of 0.5 . Conjugate $1(10 \mu \mathrm{M})$ was added to the medium at $0,2,5$, or $8 \mathrm{~h}$ postinfection. The cell lysates were prepared for Western blotting analysis to examine protein levels of NP. 
Attachment Assay. A mixture of virus (MOI =0.5) and conjugate 1 in DMEM was incubated at $37^{\circ} \mathrm{C}$ for $30 \mathrm{~min}$ and then transferred to $4{ }^{\circ} \mathrm{C}$ for $1 \mathrm{~h}$. The cell culture medium was removed from precooled $\mathrm{A} 549$ cells at $0^{\circ} \mathrm{C}$ and replaced by the virusconjugate mixtures. The cells and virus-conjugate mixtures were further incubated for $1 \mathrm{~h}$ on ice, then the cells were washed three times with precooled PBS at $0^{\circ} \mathrm{C}$. After that, the cells were fixed with $4 \%$ paraformaldehyde at $37^{\circ} \mathrm{C}$ for $0.5 \mathrm{~h}$, followed by three manual washes with precooled PBST. Finally, the samples were blocked with 4\% FBS in PBST at $37{ }^{\circ} \mathrm{C}$ for $1 \mathrm{~h}$, followed by NP staining using anti-NP antibodies and fluorescent labeled antibodies for the detection of the attached virus under fluorescence microscope.

Immunofluorescence Microscopy Experiment. The cells were washed three times with precooled PBS gently, fixed with 4\% paraformaldehyde. Then the cells were permeabilized with $0.5 \%$ Triton X-100 in PBST and blocked with 4\% FBS in PBST at $37^{\circ} \mathrm{C}$ for $1 \mathrm{~h}$. Finally, the anti-NP antibody and DAPI were used to detect NP protein and cell nuclei, respectively.

Hemagglutination Inhibition Assay. In a V-bottomed 96-well microplate, a threefold serial dilution of conjugate $\mathbf{1}$ in saline was mixed sufficiently with an equal volume of influenza virus (8 HA units). Subsequently, $50 \mu \mathrm{L}$ of $1 \%$ freshly prepared chicken red blood cells (cRBC) were added to each well and mixed. The plate was then incubated at RT for 30 min before observing cRBC aggregation on the plate.

Surface Plasmon Resonance (SPR) Experiment. The binding of conjugate 1 and BA to influenza HA were analyzed by a Biacore $8 \mathrm{k}$ system. Commercially available 
recombinant influenza HA was immobilized on a CM5 sensor chip by an amine coupling method. The final HA immobilized levels were typically $\sim 10,000$ RU. Subsequently, different compound concentrations were injected as analytes, using PBS$\mathrm{P}(10 \mathrm{mM}$ phosphate buffer with $2.7 \mathrm{mM} \mathrm{KCl}$ and $137 \mathrm{mM} \mathrm{NaCl}, 0.05 \%$ surfactant P20, $\mathrm{pH} 4.5$ ) as the running buffer. For binding studies, the analytes were applied at the corresponding concentrations in running buffer at a flow rate of $30 \mathrm{~mL} / \mathrm{min}$ with a contact time of $60 \mathrm{~s}$ and a dissociation time of $180 \mathrm{~s}$. The chip platforms were washed with running buffer and 50\% DMSO. The binding kinetic parameters were analyzed using a 1:1 binding curve fitting model with Biacore evaluation software (BIA evaluation 1.0.5.).

Virus Resistance Experiment. MDCK cells were seeded in a six-well plate at a density of $2 \times 10^{5}$ cells per well and incubated at $37{ }^{\circ} \mathrm{C}$ for $12 \mathrm{~h}$. Then the cells were infected with influenza A/WSN/33 $(\mathrm{MOI}=0.1)$ and treated with $5 \mu \mathrm{M}$ conjugate 1,5 $\mu \mathrm{M}$ amantadine (Sigma-Aldrich, Shanghai, China), or 1\% solvent DMSO, respectively, for $24 \mathrm{~h}$. The culture supernatants were collected and used for infection and titer detection in the next round of investigation. This procedure was repeated six times. After each round of passage, the amount of progeny virus in the medium supernatants was tested by the $\mathrm{TCID}_{50}$ assay. The virus yields from DMSO-treated cells (negative control) were normalized as $100 \%$.

\section{- RESULTS AND DISCUSSION}

Preparation of Hexavalent BA- $\alpha-C D$ Conjugate 1. Pursuing our interest in structurally modified pentacyclic triterpenes with strong antiviral activity, we 
synthesized the hexavalent BA- $\alpha$-CD conjugate via a convergent approach involving (i) the synthesis of two building blocks: hexakis 6-deoxy-6-azide-2,3-di- $O$-acetyl- $\alpha$-CD 4 and $N$-propargyl-3 $\beta$-hydroxy-lup-20(29)-en-28-amide 7. The intermediates 2-4 and 57 were synthesized from commercial available materials $\alpha-\mathrm{CD}$ and betulin, respectively, according to the literature (Supporting Information); ${ }^{43,45-47}$ (ii) the conjugation of the two building blocks by a copper (I)-catalyzed azide-alkyne cycloaddition (CuAAC) reaction under microwave irradiation (Scheme 1). The structure of conjugate 1 was unambiguous as characterized by ${ }^{1} \mathrm{H}$ NMR and ${ }^{13} \mathrm{C}$ NMR as well as by MALDI-TOF mass spectroscopy (Supporting Information). 

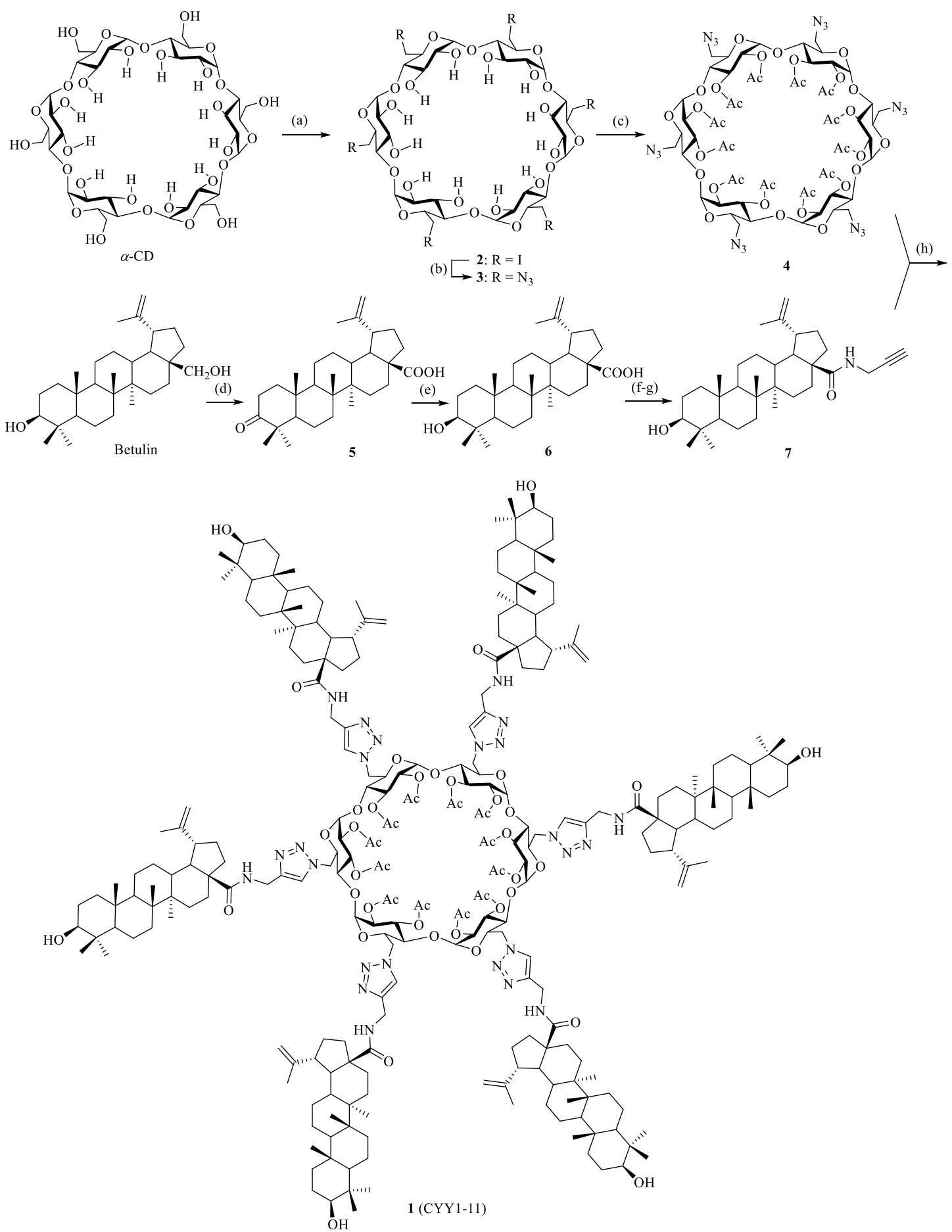

Scheme 1. Reagents and conditions: (a) $\mathrm{Ph}_{3} \mathrm{P}, \mathrm{I}_{2}, \mathrm{DMF}, \mathrm{rt}, 75 \%$; (b) $\mathrm{NaN}_{3}, \mathrm{DMF}, 80^{\circ} \mathrm{C}$, $\sim 100 \%$; (c) pyridine, DMAP, $\mathrm{Ac}_{2} \mathrm{O}, 95 \%$; (d) $\mathrm{H}_{2} \mathrm{CrO}_{4}, \mathrm{H}_{2} \mathrm{SO}_{4}$, acetone, $0{ }^{\circ} \mathrm{C} \rightarrow \mathrm{rt}, 18 \mathrm{~h}$, 63\%; (e) $\mathrm{NaBH}_{4}, \mathrm{THF}, \mathrm{rt}, 61 \%$; (f) TBTU, DIEA, THF, rt, 93\%; (g) propargylamine, $\mathrm{K}_{2} \mathrm{CO}_{3}, \mathrm{DMF}, \mathrm{rt}, 95 \%$; (h) THF- $\mathrm{H}_{2} \mathrm{O}(1: 1, \mathrm{v} / \mathrm{v}), \mathrm{Na}-L$-ascorbate, $\mathrm{CuSO}_{4}$, microwave, $100{ }^{\circ} \mathrm{C}, 1 \mathrm{~h}, 55 \%$. 
Cytotoxicity of Conjugate 1. We first evaluated the cytotoxicity of conjugate $\mathbf{1}$ in MDCK cells by the CellTiter-Glo assay. The cytotoxic concentration inhibiting $50 \%$ cell survival $\left(\mathrm{CC}_{50}\right)$ was not reached for this conjugate at concentrations of up to 200 $\mu \mathrm{M}$ (Fig. 1), suggesting a safe range for further research. As a comparison, the $\mathrm{CC}_{50}$ of BA was determined to be $31.94 \mu \mathrm{M}$, which was similar to a previous report indicating that it inhibits uninfected $\mathrm{H} 9$ lymphocyte cell growth with an $\mathrm{IC}_{50}$ value of $13 \mu \mathrm{M} \cdot{ }^{26} \mathrm{As}$ determined by MALDI-TOF MS (Fig. S1), we found that conjugate 1 in the cell culture medium is very stable and no free $\mathrm{BA}$ and $\alpha-\mathrm{CD}$ were released for 36 hours. This finding indicated that the conjugation of $\alpha-\mathrm{CD}$ with $\mathrm{BA}$ could significantly decrease the cytotoxicity of BA.

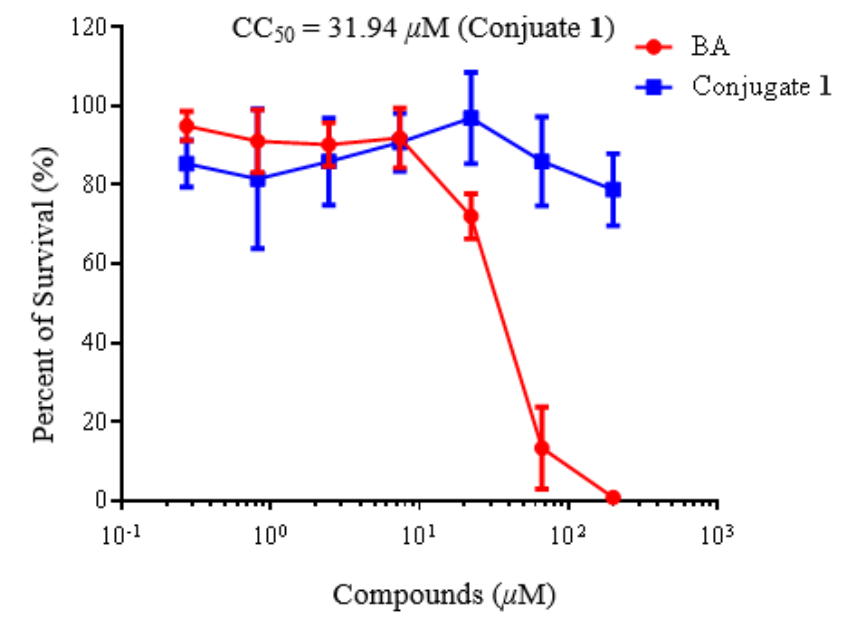

Figure 1. Effects of conjugate $\mathbf{1}$ and its parent compound BA on MDCK cell viability. MDCK cells were treated with different concentrations of BA or conjugate 1 , and cell viability was measured by the CellTiter-Glo assay. Each concentration was tested in quintuplicate, and the results are expressed as the mean and standard deviation from quintuplicate assays. 
Anti-Influenza Activity of Conjugate 1 on A/WSN/33 virus. The antiviral activity of the synthesized conjugate 1 against influenza A/WSN/33 (H1N1) virus was assessed using a CPE reduction assay, a method for the detection of the number of viable cells in a culture based on quantitation of the ATP present, which is a marker for the presence of metabolically active cells. A neuraminidase inhibitor, zanamivir (ZMV), ${ }^{48}$ was used as positive control. The preliminary antiviral assays at one concentration $(20 \mu \mathrm{M})$ demonstrated that conjugate 1 possessed a certain antiviral activity of approximately 75\% against influenza A/WSN/33 virus (Fig. 2A). MDCK cells were then treated with a 2-fold diluted series of conjugate 1. A clearly dosedependent effect of conjugate 1 against the influenza A/WSN/33 virus, with an $\mathrm{IC}_{50}$ value of $5.20 \mu \mathrm{M}(\mathrm{SI}>38.4)$, was observed (Fig. 2B). It has been reported that BA showed only weak activity against anti-influenza virus. ${ }^{40,41}$ Clearly, the conjugation of multiple copies BA onto the primary face of $\alpha$-CD increased its anti-influenza activity significantly, possibly due to the multivalent effect. In addition, compared with three analogs of $\mathbf{1}$, in which only BA was replaced by oleanolic acid (OA), echinocystic acid (EA) or ursolic acid (UA), respectively, conjugate 1 showed about 2-7 fold more potent anti-influenza virus activity. ${ }^{19}$

(A)

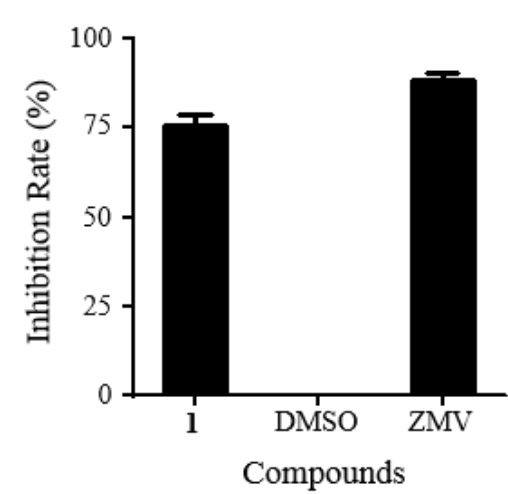

(B)

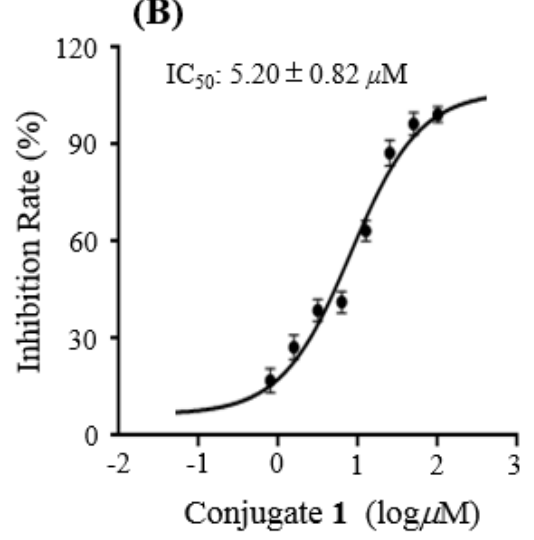

17 
Figure. 2. Inhibitory effects of conjugate 1 against influenza A/WSN/33 (H1N1) virus. (A) Preliminary screening of conjugate 1 at a concentration of $20 \mu \mathrm{M}$. Zanamivir (ZMV) acted as a positive control and DMSO acted as a negative control. (B) Inhibition curve of conjugate 1 against influenza A/WSN/33. Each concentration was tested in triplicate, and the results are expressed as mean values \pm SD percentage of inhibition activity.

\section{Microscopic Observation of Virus-Induced CPE Inhibition by Conjugate 1.}

The antiviral activity of conjugate 1 was confirmed by CPE observation using microscopy at $36 \mathrm{~h}$ postinfection. As shown in Fig. 3, the influenza virus caused serious CPEs, with the cells having a more round appearance in the DMSO control group. In comparison to the control, conjugate 1 significantly inhibited virus-induced CPEs. With regard to cytotoxicity, no cytotoxic effect caused by conjugate 1 was morphologically observed.

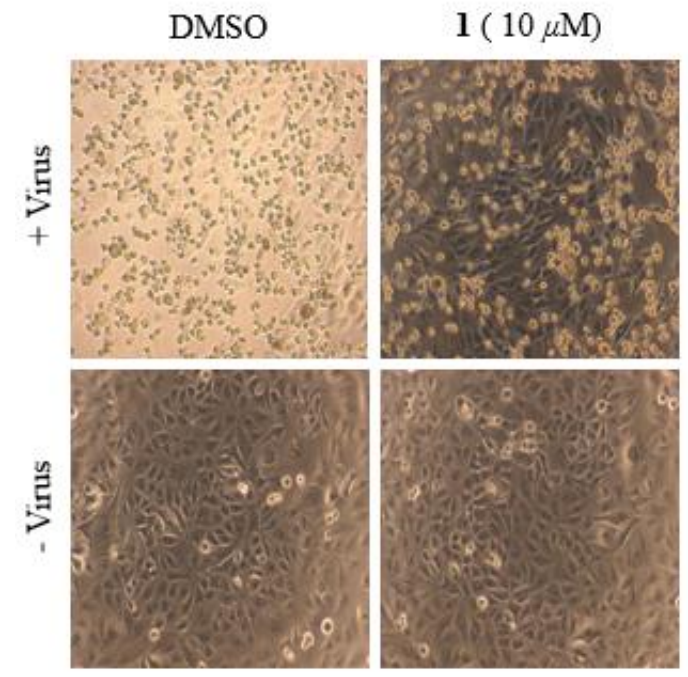

Figure 3. Conjugate 1 protects influenza A virus-infected MDCK cells. All the images were acquired at a $40 \times$ magnification with an inverted microscope (Olympus CKX41).

Conjugate 1 Inhibits Virus Entry by Targeting Virus Particles. To explore the antiviral mechanism of conjugate $\mathbf{1}$ against influenza virus, a time of addition assay was 
performed. MDCK cells were infected with influenza A/WSN/33 virus at an MOI of 0.5 and treated with conjugate $\mathbf{1}$ at different time intervals of infection (Fig. 4A). Western blotting analysis showed that compared with the DMSO control, the addition of conjugate $1(10 \mu \mathrm{M})$ significantly reduced the expression level of NP protein from 0 to $10 \mathrm{~h}$ and from 0 to $2 \mathrm{~h}$. However, no significant inhibitory effect on the NP protein level was observed in the other time intervals (Fig. 4B). This result indicated that conjugate 1 specifically act at the early stages of virus lifecycle, such as virus entry, whereas it was less effective during the viral genome replication and progeny virion release stages.

To demonstrate that conjugate $\mathbf{1}$ acted on the virus, three different experiments, including a cotreatment or a standard antiviral assay, a pretreatment of cells assay and a pretreatment of virus assay, were performed as previously reported ${ }^{22}$. In contrast to the cotreatment assay, a short pretreatment of cells (30 min) with conjugate $\mathbf{1}$ at a concentration of $10 \mu \mathrm{M}$ prior to infection showed almost no detectable effect. However, a short pretreatment of virus (30 $\mathrm{min})$ with conjugate $\mathbf{1}$ at the same concentration prior to infecting MDCK cells led to an inhibition of $64 \%$, which was comparable to that in the cotreatment assay (57\%) (Fig. 4C). These data suggested that the action target of conjugate $\mathbf{1}$ is more likely to be influenza virus, but not host cells. 

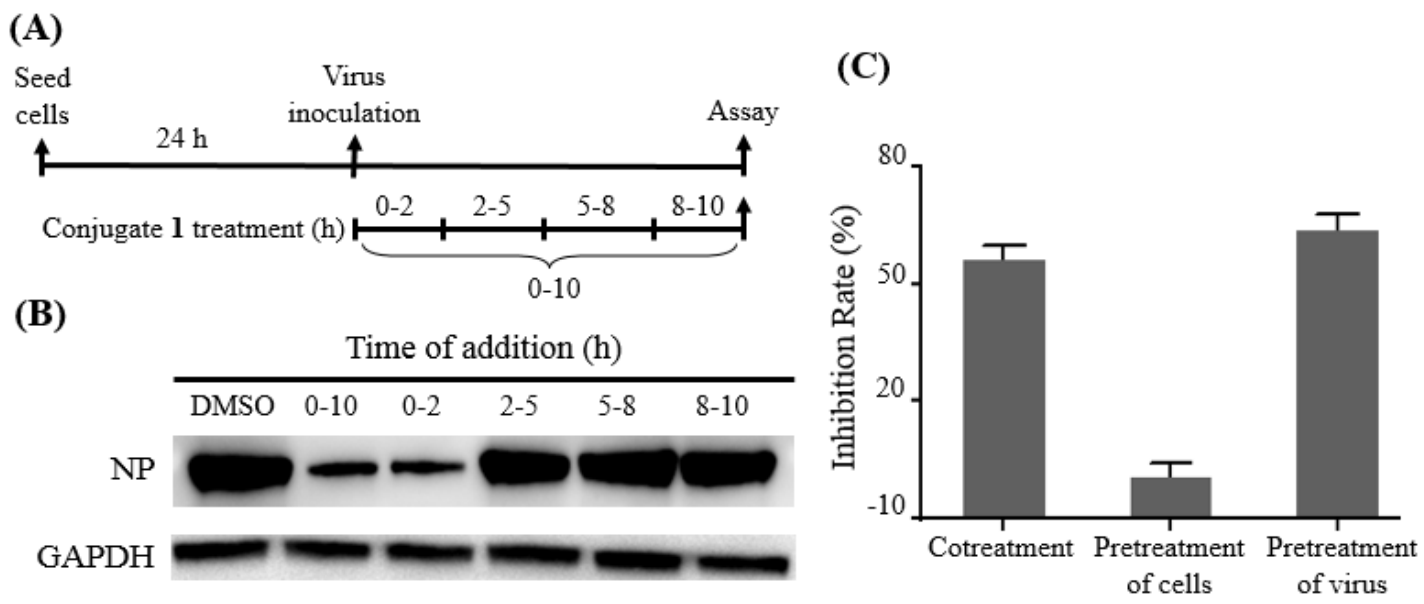

Figure 4. Anti-influenza virus mechanism studies of conjugate 1. (A) Time-of-addition assay to identify the step of the viral lifecycle targeted by conjugate $\mathbf{1}$. Conjugate 1 (10 $\mu \mathrm{M})$ was added at the designated time points. The supernatant was collected and used to evaluate NP by Western blotting analysis (B) Detection of the viral protein (as represented by NP) expression levels in influenza A virus-infected MDCK cells at five intervals, with GAPDH as a loading control. (C) Anti-influenza virus effects of conjugate 1 under three different experiments: the cotreatment assay, pretreatment of cells assay and pretreatment of virus assay.

Conjugate 1 Inhibits Virus Particle Attachment to Target Cells. In view of the above results, we further tested the effect of conjugate $\mathbf{1}$ on virus entry by performing immunofluorescence experiments. Inoculation of A549 cells with influenza A/WSN/33 virus at an MOI of 0.5 at $4{ }^{\circ} \mathrm{C}$, in the presence/absence of conjugate 1 , demonstrated remarkable differences in the accumulation of NP protein at the plasma membrane. Significant NP protein was distributed on the cellular membrane of infected cells in the absence of conjugate $\mathbf{1}$, which agreed well with the previous study that influenza viruses attach to their receptors on the cell surface under such conditions. ${ }^{49}$ In parallel 
experiments in which $5 \mu \mathrm{M}$ or $25 \mu \mathrm{M}$ of conjugate 1 was added to the culture medium, a lower amount of NP protein was detected on the cellular membrane, with almost no NP protein detected at the $50 \mu \mathrm{M}$ conjugate 1 concentration (Fig. 5). At the same time, we explored whether conjugate 1 interfered with later processes after attachment of the influenza virus. A549 cells were first infected with influenza A/WSN/33 virus at an MOI of 0.5 at $4{ }^{\circ} \mathrm{C}$ for $1 \mathrm{~h}$, afterwards, the cells were washed three times with ice-cold PBS to remove unbound viruses, and then incubated with conjugate 1 at $37{ }^{\circ} \mathrm{C}$ for $6 \mathrm{~h}$.

We observed that a large number of host cells were infected by influenza virus, with the NP protein mainly accumulating in the host nucleus, and this effect was independent of the absence or presence of conjugate $\mathbf{1}(50 \mu \mathrm{M})$ (Fig. S2). Clearly, conjugate $\mathbf{1}$ was able to disturb the attachment of influenza viruses to A549 cells but did not affect the other steps of the viral lifecycle.

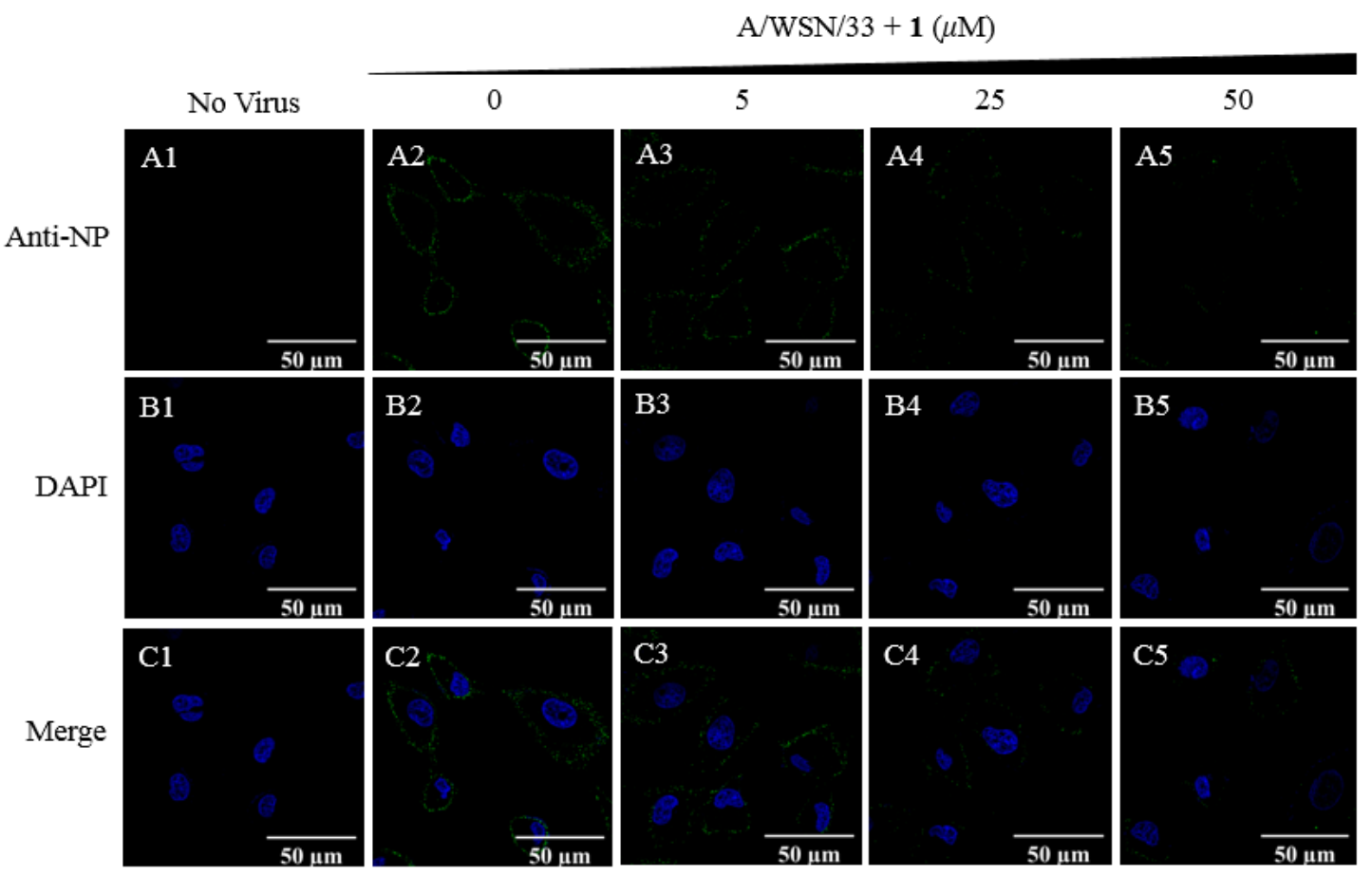

Figure 5. Effects of conjugate 1 on the attachment of influenza A virus (A/WSN/33) to A549 cells. A549 cells were prechilled for $30 \mathrm{~min}$ and infected with influenza 
$\mathrm{A} / \mathrm{WSN} / 33$ virus at an $\mathrm{MOI}=0.5$ at $4{ }^{\circ} \mathrm{C}$ in the presence of $\mathbf{1}(0,5,25$, and $50 \mu \mathrm{M})$ for $6 \mathrm{~h}$. The cells were fixed, permeabilized and stained with an anti-NP antibody (green) and DAPI (nuclear stain, blue) and were viewed under a microscope to identify the mode of action of conjugate $\mathbf{1}$.

HA is the Potential Target of Conjugate 1. The first step in influenza virus infection involves the attachment to host cells through the binding of viral surface glycoprotein HA to specific sialylated glycans on the host cells. From the time-ofaddition and immunofluorescence experiments, we found that conjugate $\mathbf{1}$ inhibited the attachment of influenza viruses to cells. Therefore, we tested the effect of conjugate $\mathbf{1}$ on virus-mediated hemagglutination of red blood cells. As expected, an anti-HA antibody, a positive control, inhibited A/WSN/33 (H1N1) HA-mediated aggregation (Fig. 6A). Similarly, conjugate 1 also significantly inhibited HA-mediated aggregation in a dose-dependent manner (Fig. 6B). This result suggested that conjugate $\mathbf{1}$ inhibited influenza A virus by targeting the HA protein.
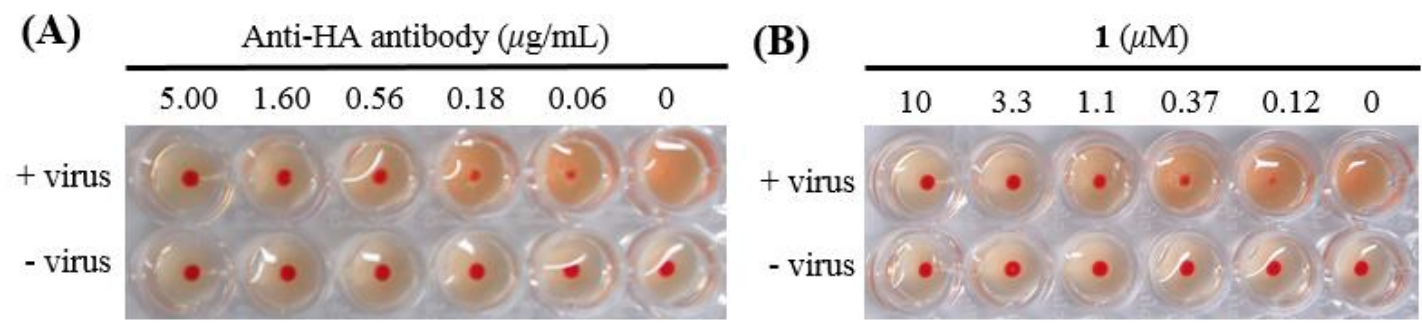

Figure 6. Conjugate 1 inhibits influenza virus-induced aggregation of cRBCs in a dosedependent manner. Chicken red blood cells were incubated with influenza A/WSN/33 (8 HA units) at room temperature for 30 min with various concentrations of conjugate 1 (a three-fold serial dilution starting from $10 \mu \mathrm{M}$ ). An anti-HA antibody was used as a positive control. 
Conjugate 1 Shows Specific Binding to the HA Protein. As the HA protein was shown to be the potential target of conjugate $\mathbf{1}$, as demonstrated by the hemagglutination inhibition assay, we further quantitatively assessed the affinity between conjugate $\mathbf{1}$ and the HA protein by surface plasmon resonance (SPR) experiments. Both conjugate $\mathbf{1}$ and its parent compound BA showed a dose-dependent resonance signal with chip-immobilized HA protein (Fig. 7 and Fig. S3). Using a 1:1 Langmuir binding model, the calculated dissociation constant $\left(K_{\mathrm{D}}\right)$ between BA and the HA protein was $\sim 86.4 \mu \mathrm{M}$, whereas the affinity was increased by approximately 49 fold when multiple BAs were conjugated to the primary face of the $\alpha$-CD scaffold ( $K_{\mathrm{D}}$ $=1.5 \mu \mathrm{M})$. Compared with BA, the increased affinity between conjugate $\mathbf{1}$ and the HA protein was mainly due to both the lower dissociation rate constant $\left(K_{\mathrm{d}}=2.56 \times 10^{-2}\right.$ $1 / \mathrm{s})$ and the higher association constant $\left(K_{\mathrm{a}}=1.70 \times 10^{4} 1 / \mathrm{Ms}\right)$.

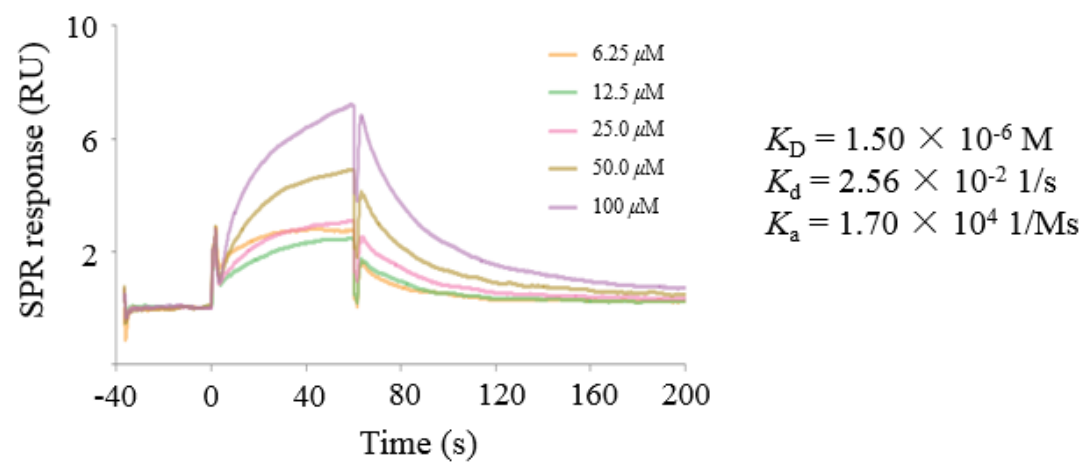

Figure 7. Conjugate 1 shows specific binding to the influenza HA protein. The HA protein was immobilized on a CM5 sensor chip by the standard amine-coupling procedure. Different concentrations of conjugate 1 were flowed over the chip surface for a contact time of $60 \mathrm{~s}$ and a dissociation time of $180 \mathrm{~s} . K_{\mathrm{D}}$ values were labeled in the graphs.

Conjugate 1 Possesses a Low Tendency to Induce Viral Resistance. To explore 
whether conjugate 1 could induce the influenza virus to become drug-resistant, a wellestablished multipassaging experiment under the constant evolutionary pressure of the drug was carried out. According to the results of the CPE inhibition assay, $5.0 \mu \mathrm{M}$ conjugate 1 was added to the culture medium to perform the multipassaging experiment (Fig. 8A). The tissue culture infective dose $\left(\mathrm{TCID}_{50}\right)$ was determined after each passage (Fig. 8B). Amantadine, which induced resistance within a few passages, was used as a positive control. In contrast, the relative $\mathrm{TCID}_{50}$ in the presence of conjugate 1 remained relatively constant during all six passages $(13 \%, 17 \%, 25 \%, 22 \%, 25 \%$ and $25 \%)$, indicating the absence of conjugate 1-resistant viruses even after six passages. The low tendency of induction of drug resistance showed that multivalent conjugate $\mathbf{1}$ was useful for overcoming the problem of drug resistance of other available antiviral drugs.

(A)

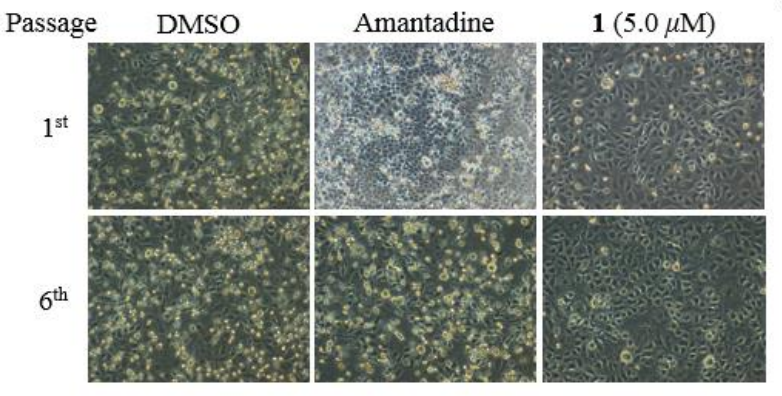

(B)

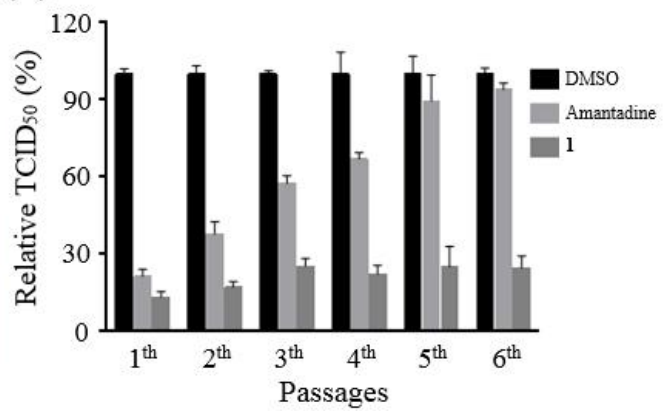

Figure 8. Continuous conjugate 1 treatment did not select for drug-resistant influenza virus variants in vitro. MDCK cells were infected with influenza A/WSN/33 $(\mathrm{MOI}=$ $0.1)$ and treated with conjugate $\mathbf{1}(5.0 \mu \mathrm{M})$, amantadine $(5.0 \mu \mathrm{M})$, or solvent DMSO (1\%). At $24 \mathrm{~h}$ post-infection, the supernatants were collected and employed for infection in the next round of investigation. (A) Microscopy observations of CPE at the $1^{\text {st }}$ and $6^{\text {th }}$ passages of a multipassaging experiment treated with either $\mathbf{1}$ or amantadine. (B) Quantitative analysis of the relative yields of progeny viruses was conducted by the 
$\mathrm{TCID}_{50}$ assay at each round for a total of six rounds of propagation. The TCID 50 values of amantadine- and conjugate 1-treated samples were calculated as the percentage of DMSO controls set as $100 \%$.

\section{- CONCLUSIONS}

In summary, a hexavalent BA- $\alpha-\mathrm{CD}$ conjugate (1) was designed and synthesized via click chemistry. Conjugate $\mathbf{1}$ displayed potent antiviral activity against infection with the $\mathrm{A} / \mathrm{WSN} / 33$ strain in MDCK cells, with an $\mathrm{IC}_{50}$ value of approximately 5.20 $\mu \mathrm{M}(\mathrm{SI}>38.5)$. The target of conjugate 1 appeared to be the surface glycoprotein HA and prevented its attachment to the host cell. More importantly, conjugate $\mathbf{1}$ showed a low tendency of induction of viral resistance. These findings may open up new opportunities for multivalent betulinic acid derivatives as potential influenza entry inhibitors.

\section{- ASSOCIATED CONTENT}

\section{Supporting Information}

The Supporting Information is available free of charge at

The effects of conjugate $\mathbf{1}$ on later viral lifecycle processes after the attachment of influenza virus; the interaction of BA with influenza HA protein; the synthesis process of the two building blocks: hexakis 6-deoxy-6-azide-2,3-di- $O$-acetyl- $\alpha$-CD 4 and $N$-propargyl-3 $\beta$-hydroxy-lup-20(29)-en-28-amide 7; ${ }^{1} \mathrm{H}$ NMR, ${ }^{13} \mathrm{C}$ NMR, DPET135, ${ }^{1} \mathrm{H}^{13}{ }^{13} \mathrm{C}$ HSQC and MALDI-TOF MS of conjugate 1 (PDF).

\section{AUTHOR INFORMATION}

\section{Corresponding Author}


*E-mail: slxiao@bjmu.edu.cn

\section{ORCID}

Sulong Xiao: 0000-0002-6852-9504

\section{Funding}

This work was supported by the National Natural Science Foundation of China [grants 21877007, 91753202 and 21702007]; and the open funding of the State Key Laboratory of Phytochemistry and Plant Resources in West China.

\section{Notes}

The authors declare no competing financial interest.

\section{- ACKNOWLEDGEMENTS}

We would like to thank Dr. Jing Wang and Dr. Fen Liu from the State Key Laboratory of Natural and Biomimetic Drugs, Peking University, for their assistance with the SPR and the $600 \mathrm{MHz}$ NMR experiments, respectively. We would also like to thank Dr. Zhong at the Centre of Medical and Health Analysis, Peking University, for the MALDI-TOF MS experiments.

\section{- ABBREVIATIONS}

BA, betulinic acid; HA, hemagglutinin; NA, neuraminidase; CD, cyclodextrin; OEG, oligo (ethylene glycol); CuAAC, Copper - catalysed azide alkyne cycloaddition; CPE, cytopathic effect; MDCK, Madin-Darby canine kidney; DMEM, Dulbecco's Modified Eagle Medium; NP, nucleoprotein; SI, selectivity index; MOI, multiplicity of infection; SPR, surface plasmon resonance; PBS, phosphate buffered solution. 


\section{- REFERENCES}

1. Lamb, R. A.; Choppin, P. W. The gene structure and replication of influenza virus. Annu. Rev. Biochem. 1983, 52, 467-506.

2. Sethy, B.; Hsieh, C. F.; Lin, T. J.; Hu, P. Y.; Chen, Y. L.; Lin, C. Y.; Tseng, S. N.; Horng, J. T.; Hsieh, P. W. Design, synthesis, and biological evaluation of itaconic acid derivatives as potential anti-influenza agents. J. Med. Chem. 2019, 62, 2390-2403.

3. Organization., W. H. Influenza (seasonal). Available at: https://www.who.int/en/news-room/fact-sheets/detail/influenza-(seasonal). Accessed on November 6, 2018.

4. Carrat, F.; Flahault, A. Influenza vaccine: the challenge of antigenic drift. Vaccine 2007, 25, 6852-6862.

5. Deyde, V. M.; Xu, X.; Bright, R. A.; Shaw, M.; Smith, C. B.; Zhang, Y.; Shu, Y.; Gubareva, L. V.; Cox, N. J.; Klimov, A. I. Surveillance of resistance to adamantanes among influenza $\mathrm{A}(\mathrm{H} 3 \mathrm{~N} 2)$ and $\mathrm{A}(\mathrm{H} 1 \mathrm{~N} 1)$ viruses isolated worldwide. J. Infect. Dis. 2007, 196, 249-257.

6. Furuse, Y.; Suzuki, A.; Oshitani, H. Large-scale sequence analysis of M gene of influenza A viruses from different species: mechanisms for emergence and spread of amantadine resistance. Antimicrob. Agents Chemother. 2009, 53, 4457-4463.

7. Mishin, V. P.; Hayden, F. G.; Gubareva, L. V. Susceptibilities of antiviral-resistant influenza viruses to novel neuraminidase inhibitors. Antimicrob. Agents Chemother. 2005, 49, 4515-4520.

8. Meijer, A.; Lackenby, A.; Hungnes, O.; Lina, B.; van-der-Werf, S.; Schweiger, B.; 
Opp, M.; Paget, J.; van-de-Kassteele, J.; Hay, A.; Zambon, M. Oseltamivir-resistant influenza virus A (H1N1), Europe, 2007-08 season. Emerg. Infect. Dis. 2009, 15, 552560.

9. Mammen, M.; Choi, S. K.; Whitesides, G. M. Polyvalent interactions in biological systems: implications for design and use of multivalent ligands and inhibitors. Angew. Chem. Int. Ed. Engl. 1998, 37, 2754-2794.

10. Cusack S Fau - Ruigrok, R. W.; Ruigrok Rw Fau - Krygsman, P. C.; Krygsman Pc Fau - Mellema, J. E.; Mellema, J. E. Structure and composition of influenza virus: A small-angle neutron scattering study. J. Mol. Biol. 1985, 186, 565-582.

11. Sigal, G. B.; Mammen, M.; Dahmann, G.; Whitesides, G. M. Polyacrylamides bearing pendant $\alpha$-sialoside groups strongly inhibit agglutination of erythrocytes by influenza virus: The strong inhibition reflects enhanced binding through cooperative polyvalent interactions. J. Am. Chem. Soc. 1996, 118, 3789-3800.

12. Makimura, Y.; Watanabe, S.; Suzuki, T.; Suzuki, Y.; Ishida, H.; Kiso, M.; Katayama, T.; Kumagai, H.; Yamamoto, K. Chemoenzymatic synthesis and application of a sialoglycopolymer with a chitosan backbone as a potent inhibitor of human influenza virus hemagglutination. Carbohydr. Res. 2006, 341, 1803-1808.

13. Lee, C. M.; Weight, A. K.; Haldar, J.; Wang, L.; Klibanov, A. M.; Chen, J. Polymerattached zanamivir inhibits synergistically both early and late stages of influenza virus infection. Proc. Nat. Acad. Sci. USA. 2012, 109, 20385-20390.

14. Zanini, D.; Roy, R. Novel Dendritic alpha-Sialosides: Synthesis of Glycodendrimers Based on a 3,3'-Iminobis(propylamine) Core. J.Org. Chem. 1996, 61, 
7348-7354.

15. Ogata, M.; Umemura, S.; Sugiyama, N.; Kuwano, N.; Koizumi, A.; Sawada, T.; Yanase, M.; Takaha, T.; Kadokawa, J. I.; Usui, T. Synthesis of multivalent sialyllactosamine-carrying glyco-nanoparticles with high affinity to the human influenza virus hemagglutinin. Carbohydr. Polym. 2016, 153, 96-104.

16. Lauster, D.; Glanz, M.; Bardua, M.; Ludwig, K.; Hellmund, M.; Hoffmann, U.; Hamann, A.; Böttcher, C.; Haag, R.; Hackenberger, C. P. R.; Herrmann, A. Multivalent peptide-nanoparticle conjugates for influenza-virus inhibition. Angew. Chem. Int. Ed. Engl. 2017, 56, 5931-5936.

17. Papp, I.; Sieben, C.; Ludwig, K.; Roskamp, M.; Böttcher, C.; Schlecht, S.; Herrmann, A.; Haag, R. Inhibition of influenza virus infection by multivalent sialicacid-functionalized gold nanoparticles. Small 2010, 6, 2900-2906.

18. Marra, A.; Moni, L.; Pazzi, D.; Corallini, A.; Bridi, D.; Dondoni, A. Synthesis of sialoclusters appended to calix[4]arene platforms via multiple azide-alkyne cycloaddition. New inhibitors of hemagglutination and cytopathic effect mediated by BK and influenza A viruses. Org. Biomol. Chem. 2008, 6, 1396-1409.

19. Xiao, S.; Si, L.; Tian, Z.; Jiao, P.; Fan, Z.; Meng, K.; Zhou, X.; Wang, H.; Xu, R.; Han, X.; Fu, G.; Zhang, Y.; Zhang, L.; Zhou, D. Pentacyclic triterpenes grafted on CD cores to interfere with influenza virus entry: A dramatic multivalent effect. Biomaterials 2016, 78, 74-85.

20. Li, Y.; Gao, Y.; Wang, B.; Hao, J.; Hu, J.; Ju, Y. Natural triterpenoid- and oligo(ethylene glycol)-pendant-containing block and random copolymers: aggregation 
and pH-controlled release. Chem. Asian J. 2018, 13, 2723-2729.

21. Yang, Y.; He, H.-J.; Chang, H.; Yu, Y.; Yang, M.-B.; He, Y.; Fan, Z.-C.; Iyer, S. S.; $\mathrm{Yu}, \mathrm{P}$. Multivalent oleanolic acid human serum albumin conjugate as nonglycosylated neomucin for influenza virus capture and entry inhibition. Eur. J. Med. Chem. 2018, $143,1723-1731$.

22. Yu, M.; Si, L.; Wang, Y.; Wu, Y.; Yu, F.; Jiao, P.; Shi, Y.; Wang, H.; Xiao, S.; Fu, G.; Tian, K.; Wang, Y.; Guo, Z.; Ye, X.; Zhang, L.; Zhou, D. Discovery of pentacyclic triterpenoids as potential entry inhibitors of influenza viruses. J. Med. Chem. 2014, 57, 10058-10071.

23. Xiao, S.; Tian, Z.; Wang, Y.; Si, L.; Zhang, L.; Zhou, D. Recent progress in the antiviral activity and mechanism study of pentacyclic triterpenoids and their derivatives. Med. Res. Rev. 2018, 38, 951-976.

24. Liang, S.; Li, M.; Yu, X.; Jin, H.; Zhang, Y.; Zhang, L.; Zhou, D.; Xiao, S. Synthesis and structure-activity relationship studies of water-soluble $\beta$-cyclodextringlycyrrhetinic acid conjugates as potential anti-influenza virus agents. Eur. J. Med. Chem. 2019, 166, 328-338.

25. Krasutsky, P. A. Birch bark research and development. Nat. Prod. Rep. 2006, 23, 919-942.

26. Fujioka, T.; Kashiwada, Y.; Kilkuskie, R. E.; Cosentino, L. M.; Ballas, L. M.; Jiang, J. B.; Janzen, W. P.; Chen, I. S.; Lee, K. H. Anti-AIDS agents .11. Betulinic acid and platanic acid as anti-HIV principles from syzigium-claviflorum, and the anti-HIV activity of structurally related triterpenoids. J. Nat. Prod. 1994, 57, 243-247. 
27. Kashiwada, Y.; Hashimoto, F.; Cosentino, L. M.; Chen, C. H.; Garrett, P. F.; Lee, K. H. Betulinic acid and dihydrobetulinic acid derivatives as potent anti-HIV agents. $J$. Med. Chem. 1996, 39, 1016-1017.

28. Qian, K.; Yu, D.; Chen, C. H.; Huang, L.; Morris-Natschke, S. L.; Nitz, T. J.; Salzwedel, K.; Reddick, M.; Allaway, G. P.; Lee, K. H. Anti-AIDS agents. 78. Design, synthesis, metabolic stability assessment, and antiviral evaluation of novel betulinic acid derivatives as potent anti-human immunodeficiency virus (HIV) agents. J. Med. Chem. 2009, 52, 3248-3258.

29. Qian, K.; Bori, I. D.; Chen, C. H.; Huang, L.; Lee, K. H. Anti-AIDS agents 90. Novel C-28 modified bevirimat analogues as potent hiv maturation inhibitors. J. Med. Chem. 2012, 55, 8128-8136.

30. Zhao, Y.; Gu, Q.; Morris-Natschke, S. L.; Chen, C. H.; Lee, K. H. Incorporation of privileged structures into bevirimat can improve activity against wild-type and bevirimat-resistant HIV-1. J. Med. Chem. 2016, 59, 9262-9268.

31. Dang, Z.; Lai, W.; Qian, K.; Ho, P.; Lee, K. H.; Chen, C. H.; Huang, L. Betulinic acid derivatives as human immunodeficiency virus type 2 (HIV-2) inhibitors. J. Med. Chem. 2009, 52, 7887-7891.

32. Martin, D. E.; Blum, R.; Wilton, J.; Doto, J.; Galbraith, H.; Burgess, G. L.; Smith, P. C.; Ballow, C. Safety and pharmacokinetics of Bevirimat (PA-457), a novel inhibitor of human immunodeficiency virus maturation, in healthy volunteers. Antimicrob. Agents Chemother. 2007, 51, 3063-3066.

33. Mayaux, J. F.; Bousseau, A.; Pauwels, R.; Huet, T.; Henin, Y.; Dereu, N.; Evers, 
M.; Soler, F.; Poujade, C.; De Clercq, E.; et al. Triterpene derivatives that block entry of human immunodeficiency virus type 1 into cells. Proc. Natl. Acad. Sci. USA. 1994, $91,3564-3568$.

34. Sun, I. C.; Chen, C. H.; Kashiwada, Y.; Wu, J. H.; Wang, H. K.; Lee, K. H. AntiAIDS agents 49. Synthesis, anti-HIV, and anti-fusion activities of IC9564 analogues based on betulinic acid. J. Med. Chem. 2002, 45, 4271-4275.

35. Huang, L.; Ho, P.; Lee, K. H.; Chen, C. H. Synthesis and anti-HIV activity of bifunctional betulinic acid derivatives. Bioorg. Med. Chem. 2006, 14, 2279-2289.

36. Smith, P. F.; Ogundele, A.; Forrest, A.; Wilton, J.; Salzwedel, K.; Doto, J.; Allaway, G. P.; Martin, D. E. Phase I and II study of the safety, virologic effect, and pharmacokinetics/pharmacodynamics of single-dose $3-O-\left(3^{\prime}, 3^{\prime}-\right.$ dimethylsuccinyl)betulinic acid (bevirimat) against human immunodeficiency virus infection. Antimicrob. Agents Chemother. 2007, 51, 3574-3581.

37. Cragg, G. M.; Grothaus, P. G.; Newman, D. J. New horizons for old drugs and drug leads. J. Nat. Prod. 2014, 77, 703-723.

38. Nowicka-Sans, B.; Protack, T.; Lin, Z.; Li, Z.; Zhang, S.; Sun, Y.; Samanta, H.; Terry, B.; Liu, Z.; Chen, Y.; Sin, N.; Sit, S. Y.; Swidorski, J. J.; Chen, J.; Venables, B. L.; Healy, M.; Meanwell, N. A.; Cockett, M.; Hanumegowda, U.; Regueiro-Ren, A.; Krystal, M.; Dicker, I. B. Identification and characterization of BMS-955176, a secondgeneration HIV-1 maturation inhibitor with improved potency, antiviral spectrum, and Gag polymorphic coverage. Antimicrob. Agents Chemother. 2016, 60, 3956-3969.

39. Regueiro-Ren, A.; Liu, Z.; Chen, Y.; Sin, N.; Sit, S. Y.; Swidorski, J. J.; Chen, J.; 
Venables, B. L.; Zhu, J.; Nowicka-Sans, B.; Protack, T.; Lin, Z.; Terry, B.; Samanta, H.; Zhang, S.; Li, Z.; Beno, B. R.; Huang, X. S.; Rahematpura, S.; Parker, D. D.; Haskell, R.; Jenkins, S.; Santone, K. S.; Cockett, M. I.; Krystal, M.; Meanwell, N. A.; Hanumegowda, U.; Dicker, I. B. Discovery of BMS-955176, a second generation HIV1 maturation inhibitor with broad spectrum antiviral activity. ACS Med. Chem. Lett. 2016, $7,568-572$.

40. Baltina, L. A.; Flekhter, O. B.; Nigmatullina, L. R.; Boreko, E. I.; Pavlova, N. I.; Nikolaeva, S. N.; Savinova, O. V.; Tolstikov, G. A. Lupane triterpenes and derivatives with antiviral activity. Bioorg. Med. Chem. Lett. 2003, 13, 3549-3552.

41. Gong, K. K.; Li, P. L.; Qiao, D.; Zhang, X. W.; Chu, M. J.; Qin, G. F.; Tang, X. L.; Li, G. Q. Cytotoxic and antiviral triterpenoids from the mangrove plant Sonneratia paracaseolaris. Molecules 2017, 22, 1319.

42. Tung, N. H.; Kwon, H. J.; Kim, J. H.; Ra, J. C.; Kim, J. A.; Kim, Y. H. An antiinfluenza component of the bark of Alnus japonica. Arch. Pharm. Res. 2010, 33, 363367.

43. Baer, H. H.; Berenguel, A. V.; Shu, Y. Y.; Defaye, J.; Gadelle, A.; Gonzalez, F. S. Improved preparation of hexakis(6-deoxy)cyclomaltohexaose and heptakis(6deoxy)cyclomaltoheptaose. Carbohydr. Res. 1992, 228, 307-314.

44. Xiao, S.; Wang, Q.; Si, L.; Shi, Y.; Wang, H.; Yu, F.; Zhang, Y.; Li, Y.; Zheng, Y.; Zhang, C.; Wang, C.; Zhang, L.; Zhou, D. Synthesis and anti-HCV entry activity studies of $\beta$-cyclodextrin-pentacyclic triterpene conjugates. ChemMedChem. 2014, 9, 10601070. 
45. Gadelle, A.; Defaye, J. Selective halogenation at primary positions of cyclomaltooligosaccharides and a synthesis of per-3,6-anhydro cyclomaltooligosaccharides. Angew. Chem. Int. Ed. Engl. 1991, 30, 78-80.

46. Kim, D. S. H. L.; Chen, Z. D.; Nguyen, T.; Pezzuto, J. M.; Qiu, S. X.; Lu, Z. Z. A concise semi-synthetic approach to betulinic acid from betulin. Synthetic Commun. 1997, 27, 1607-1612.

47. Flekhter, O. B.; Nigmatullina, L. R.; Baltina, L. A.; Karachurina, L. T.; Galin, F. Z.; Zarudii, F. S.; Tolstikov, G. A.; Boreko, E. I.; Pavlova, N. I.; Nikolaeva, S. N.; Savinova, O. V. Synthesis of betulinic acid from betulin extract and study of the antiviral and antiulcer activity of some related terpenoids. Pharm. Chem. J. 2002, 36, 484-487.

48. Colman, P. M. Zanamivir: an influenza virus neuraminidase inhibitor. Expert Rev. Anti Infect. Ther. 2005, 3, 191-199.

49. Lees, W. J.; Spaltenstein, A.; Kingery-Wood, J. E.; Whitesides, G. M. Polyacrylamides bearing pendant alpha-sialoside groups strongly inhibit agglutination of erythrocytes by influenza A virus: multivalency and steric stabilization of particulate biological systems. J. Med. Chem. 1994, 37, 3419-3433. 